\title{
Malnutrition and the family: deprivation in kwashiorkor
}

\section{By Janet Goodall, Paediatric Department, North Staffordshire Hospital Centre, Stoke-on-Trent}

Every paediatrician in the United Kingdom sees children who are under-sized and whose failure to thrive can be attributed to no other cause than to deprivation. This may have been overt or covert, associated with frank neglect or with a lack of warmth in relationships.

Social deprivation was thought to be the cause of their stunting in at least onethird of short normal children (below the $3^{\text {rd }}$ percentile-for-height) studied in Newcastle upon Tyne (Parkin \& Lacey, 1974). Health visitors may report that they rarely detect the smell of cooking or interrupt a sit-down meal in many sociallydeprived homes. Here, part of the failure to thrive may be due to frank malnutrition arising from both an inadequate diet and mothers' confessed inability to cook. Weight goes up dramatically on hospital admission.

Emotional deprivation has been recognized for seven centuries. Frederick II in the thirteenth century is said to have tried to bring up a group of newborn babies in absolute silence in an attempt to discover the natural evolution of language. The children all failed to thrive to the point of death, history relating that 'they could not live without the petting . . . and loving words of their foster mothers'. As recently as 1915 , it was found that $90 \%$ of the infants in Baltimore orphanages and foundling homes died within I year of admission in spite of adequate physical care. Clearly, growth depends on more than food.

When the dietary intake is known to be good, the actual mechanism by which emotional deprivation causes failure to thrive remains something of a mystery. There is some inconsistent evidence of malabsorption, but more convincing evidence for hormonal disturbance in deprived children. Deficient growth hormone output and poor adrenocorticotrophic hormone responsiveness have been found in some, hormonal and emotional balance recovering together (Powell et al. 1967). Retarded bone age is a common finding which could be due either to malabsorption or to endocrine malfunction, but in recent years there has been more evidence of pituitary and hypothalamic involvement in deprivation dwarfism (Gardner, 1972).

Whatever the humoral processes underlying such failure to thrive, these children not only show physical and often developmental retardation: they also have the same affect as that described in his street boys by Dr Barnardo last century: '.. a glazed stupor, a vacant stare, a sullen apathetic fear and misery that go to the heart. A little lamp with the light gone out' (Williams, 1943). Withdrawal and hypotonia, producing a characteristic 'frog' position, have been described in more recent years (Gardner, 1972; Clancy \& McBride, 1975). In chronic deprivation, 
several writers comment on the look in the child's eye as being 'incongruously alert and watchful' (Robertson, 1962) or like a 'radar gaze' (Patten \& Gardner, 1963). It is worth tracing the evolution of this emotionally-disturbed state.

When deprivation takes place abruptly, the resultant acute distress reaction has been described in terms of three phases (Bowlby, 1971; Robertson \& Robertson, 197 $\mathrm{I}$ ). The first phase is one of protest, when the infant cries and screams, panics and clings to his mother if she visits. After a few days this is replaced by despair, when the child is more withdrawn and appears miserable and unhappy: eating and sleeping problems are common at this time. The third phase is one of detachment, when the child withdraws and seems to lose interest in his parents if they visit. This acute distress reaction is most likely to be seen between 7 months and 4 years of age, and according to Rutter (1975), is commoner in children with little experience of visiting other people, who have had a recent traumatic separation or come from an unhappy home and those who find emotional adjustment difficult. There is also some suggestion that boys are more vulnerable than girls (Rutter, 1975).

Putting the lower age limit for acute distress reaction as 7 months is in accordance with the age at which children are thought to have firmly bonded to the people most familiar to them (Yarrow \& Goodwin, 1974). However, we now deduce that babies are programmed for relationships even before birth, as within the first few days of life every perceptive pathway has been found to respond best to human stimulation. Thus, a baby prefers to see a human face, to hear a female voice, to touch a soft, warm (skin) surface. By 3 days, he can show preference for the smell of his own mother and the taste of milk. He smiles responsively as early as he is expected (and therefore stimulated) to do so, and by 3 weeks of age gives most fixed attention to his own mother's face, even when she is seen in a group (Stone et al. 1974). The closer the contact, the quicker and stronger the bonding.

The extent of contact achieved with her infant largely depends on the mother. The uniquely human method of breast feeding 'en face' is the ideal way of enabling a mother to watch her infant and respond to his enjoyment, so strengthening their mutual bonds of affection. Fathers have been found to be even more elated than mothers when given evidence of their child's response to parental interest. This involvement and support of the father encourages both mother and child to enjoy their growing relationship and so establishes emotional and social security for that family nucleus. Parents are thought to bond to the child much earlier than the child bonds to them (Klaus \& Kennell, 1976) and interference with parental bonding may predispose to later abuse of the child (Lynch, 1975).

Such attached parents will see to it that when their child's nutritional needs outgrow a diet of milk they continue to make adequate provision ensuring that it is appropriately presented and that their active participation in feeding it to the child is continued. In such an environment, the child's initial pleasure in his parents' company grows into love and separation from them brings the despair of an inexplicable bereavement.

Conversely, lack of personal attention by the parents will thwart the infant's 
attempts to bond with them. Anxiety, depression and withdrawal may follow, shown in a child as constant crying, sleeplessness or later, stupor: these may all build up increasing parental antipathy towards him. If the parents have other problems such as marital disharmony or economic crisis, the child is likely to be gradually deprived of dietary supervision as well as affection and may also lose appetite. We have already seen how absorption and growth may falter in a cold emotional climate. In adult life, emotional malaise whittles the waist-line: in childhood it flattens the growth curve.

In both acute and chronic deprivation, a family member already known to the child may offer solace, so helping recovery, but the process is likely to be slow. Further weight loss may be expected before a new relationship becomes well established.

\section{Kwashiorkor and emotional deprivation}

Against the background of this knowledge I went in 1969 to work at New Mulago Hospital, Kampala and, until 1972, saw patients there with more severe malnutrition than I have seen either before or since. Many of the first cases of kwashiorkor had a look in their eye which was far more familiar to me than the clinical entity itself. Their sad, hurt unresponsiveness spoke of emotional deprivation and it was this tell-tale look that provoked a study of their family backgrounds.

A group of 107 children with kwashiorkor were compared with III wellnourished control children carefully selected to avoid possible bias (Table 1).

Unmatched comparison of kwashiorkor patients with controls showed up significant differences on the basis of age, sex and tribe (Table 2).

Table I. Nature of the well-nourished control group

$\begin{array}{lcc} & \text { Total } & \text { Matched } \\ \text { Sickle cell disease } & 38 & 25 \\ \text { Surgical problems } & 19 & 9 \\ \text { Meningitis (non-tuberculous) } & 34 & 9 \\ \text { Normal sibling } & 15 & 5 \\ \text { Other } & 5 & 2 \\ & 111 & 50\end{array}$

Table 2. Age and sex differences (unmatched) in well-nourished controls and children with kwashiorkor

\begin{tabular}{|c|c|c|c|c|c|c|}
\hline \multirow[b]{2}{*}{$\begin{array}{c}\text { Age } \\
\text { (months) }\end{array}$} & \multicolumn{3}{|c|}{ Kwashiorkor } & \multicolumn{3}{|c|}{ Control } \\
\hline & o & $Q$ & Total & o & $Q$ & Total \\
\hline$<6-12$ & - & - & - & 4 & 4 & 8 \\
\hline $6-11$ & 4 & 2 & 6 & II & 5 & 16 \\
\hline $12-23$ & 28 & 20 & $4^{8}$ & 27 & 10 & 37 \\
\hline $24-35$ & 17 & 12 & 29 & 13 & 4 & 17 \\
\hline $\begin{array}{c}36-39 \\
>5 \text { years }\end{array}$ & 7 & II & 18 & 18 & 9 & 27 \\
\hline & 56 & $5^{1}$ & 107 & 73 & $3^{8}$ & III \\
\hline
\end{tabular}


Age. The control group had a wide age-range, but most children with kwashiorkor were between 12 and 35 months old.

Sex. Up to 3 years of age most kwashiorkor patients were boys (forty-nine male, thirty-four female) reflecting the sex ratio in the population and also the increased vulnerability of young boys to stress (Rutter, 1972, 1975). Over 3 years of age, girls predominated (seven male, seventeen female), probably reflecting the traditionally poorer female intake of protein (Bennett, 1963).

Tribe. Seventy-eight of the I I controls were Baganda, a preponderance to be expected in Kampala, the capital of their kingdom. Sixty of the 107 children with kwashiorkor were from families who had moved into Kampala from other tribal areas (Table 3). Over one-third of these were from Ruanda-Burundi, a cattlerearing people singularly unsuited for city life and, off their own territory, without land for cultivation. There was thus serious economic disadvantage in being born into an immigrant family. It was, though, a potential emotional disadvantage to be born into a Baganda family, as tribal custom here included the dispatch of a hitherto suckling child out of the family home during the next pregnancy. This was lest the mother's abdominal swelling 'infected' the infant, but all too often the move actually precipitated the oedema of kwashiorkor which it had been misguidedly designed to avoid.

Table 3. Tribal differences (local or immigrant; unmatched) in well-nourished controls and children with kwashiorkor

\begin{tabular}{|c|c|c|c|c|}
\hline \multirow[b]{2}{*}{$\begin{array}{c}\text { Uganda: Baganda } \\
\text { Other tribes }\end{array}$} & \multicolumn{2}{|c|}{ Kwashiorkor } & \multicolumn{2}{|c|}{ Control } \\
\hline & $\begin{array}{l}47 \\
22\end{array}$ & (47) & $\begin{array}{l}78 \\
22\end{array}$ & (78) \\
\hline $\begin{array}{l}\text { Ruanda-Burundi } \\
\text { Kenya } \\
\text { Sudan } \\
\text { Tanzania }\end{array}$ & $\begin{array}{r}23 \\
7 \\
5 \\
3\end{array}$ & $(60)$ & $\begin{array}{r}7 \\
2 \\
2 \\
-\end{array}$ & (33) \\
\hline Total & & 107 & & III \\
\hline
\end{tabular}

Matching for age, sex and tribe was designed to smooth out these discrepancies and fifty children in each group were so matched.

\section{Comparison of the matched groups}

(a) Breast-feeding and weaning. The majority of East African babies are breast fed, but none of the fifty children with kwashiorkor in this study was receiving any breast feeds at all. (Table $4 ; P=0 \cdot 00004$ ).

Table 4. Incidence of breast-feeding in well-nourished controls and children with kwashiorkor

$\begin{array}{lcc} & \text { Kwashiorkor } & \text { Control } \\ \text { Yes } & - & 13 \\ \text { No } & 50 & 37\end{array}$

The difference between groups was significant: $P=0.00004$ (Fisher exact probability test). 
Bonding between the Ugandan mother and child must be about as strong as it ever can be. The Muganda woman's dress seems to have been designed with babies in mind; it has a voluminous skirt for pregnancy, an easily-opened bodice for breast feeding and a surrounding flounce at the waist to tie the infant to her back. From birth, the child is thus on the mother's back, at her breast or in her bed: together they are almost a unity until the child is weaned. 'The right time' for weaning is approximately 18 months of age, by which time the symbiosis is extraordinarily well established. Absence of millk, or a well child's refusal to suck (and starting to bite), may also provoke weaning, but are acceptable as reasonable causes. Bad causes would be dead or departed and pregnant or working mothers: an uncertain weaning history is deemed adverse as it is likely to be due to lack of contact with the mother.

Table 5. Weaning history of well-nourished controls and children with kwashiorkor

Reasons for weaning
Good: Not weaned
No milk
Refused
Right time
Bad: No mother
Pregnancy
Mother to wort
Other-uncertsin

$\begin{array}{cc}\text { Kwashiorkor } & \text { Control } \\ - & 13 \\ 8 & 10 \\ - & 5 \\ 11 & 9 \\ 8 & 1 \\ 14 & 8 \\ 2 & - \\ 7 & 4 \\ 50 & 50\end{array}$

The difference between groups was significant: $P<0.005\left(X^{2}\right.$ teat).

Mothers or attendants were asked what had been the reasons for weaning, remembering that thirteen of the control group were still breast feeding (Table 5). Over-all, there was found to be a significant difference between good and bad reasons, the bad reasons being mostly in the kwashiorkor group $(P<0.005)$. In most of these, weaning had taken place abruptly (see also Table 8).

(b) Stability of marriage. Over twenty-four kwashiorkor children had been weaned for 'bad' reasons: eight had no mother and two were illegitimate with working mothers. Whereas thirty-one children in the control group had parents consistently living together, only twenty couples whose child had kwashiorkor were doing so (Table $6 ; P<0.05$ ). The other partnerships had proved to be unstable for a variety of reasons, including two deaths. 'Half-separation' refers to fathers working away from home, or there being admitted rifts between the parents involving recurrent comings and goings. 
Table 6. Parents' relationship in well-nourished controls and children with kwashiorkor

Together
Separated
Half separated
Unmarried
Uncertain
One dead
Total

$\begin{array}{cc}\text { Kwashiorkor } & \text { Control } \\ 20 & 31^{\circ} \\ 20 & 9 \\ 4 & 6 \\ 5 & 2 \\ 1 & 0 \\ 0 & 2 \\ 50 & 50\end{array}$

-The difference between groups was significant: $P<0.05\left(X^{2}\right.$ test).

(c) Parent-child relationship. Break-up of a marriage in East Africa is commonly associated with a break in the parent-child relationship at the same time. By law, a child belongs to the father (Welbourne, 1963). If a nursing mother runs away from her husband, she may abruptly stop breast feeding and leave the child with him. Even if she takes the infant with her, she may send him back later, expecially if he needs medical care or is ready for school. In any of these circumstances and also on the sudden death of his wife, a father may hand the child over to another female relative so that loss of the mother and of the familiar home take place together. Thus, although the relationship of a Ugandan child and mother can be amongst the closest in the world, it is also open to major threats.

(d) The extended family. It was frequently found that a child was not living with the parents and, on enquiry, children with kwashiorkor were found to be far less likely to be living with both parents than was the control group (Table 7; $P<0.005$ ). Occasionally a child had been moved around from one relative to another, a process clearly likely to induce profound emotional upset.

Table 7. Family members with whom child was usually with, for well-nourished controls and children with kwashiorkor

$\begin{array}{lcc} & \text { Kwashiorkor } & \text { Control } \\ \text { Both parents } & 16 & 33 \\ \text { Mother } & 7 & 9 \\ \text { Father } & 5 & 0 \\ \text { Grandparent } & 9 & 5 \\ \text { Other } & 1 & 0 \\ \text { Varied } & 12 & 3 \\ \text { Total } & 50 & 50\end{array}$

The difference between groups was significant: $P<0.005\left(X^{2}\right.$ test).

(e) The exiled reanling. Although twenty couples whose child had kwashiorkor were living together (Table 4), only sixteen patients were actually living with their parents (Table 7). The remaining four were Baganda who, according to custom, had been sent away during their mother's next pregnancy. 
Twenty-eight children with kwashiorkor had been sent away from home compared with eight controls $(P<0.005)$. Of these, at least seventeen $(P=0 \cdot 000022)$ were known to have been weaned at the time of the move (Table 8). Because of the high incidence of sequential child-minders, it was not always clear whether weaning and banishment had occurred together. The commonest reasons for sending the child away were pregnancy and parental separation or death.

Table 8. Incidence of child being sent away for well-nourished controls and children with kwashiorkor: association with weaning

Child never sent away Child sent away: at weaning at other times

\section{Kwashiorkor}

22

17

II

\section{Control}

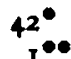

7

The difference between the groups was significant: $\bullet P<0.005, \bullet P=0.000022\left(\chi^{2}\right.$ tests).

For many of these children, therefore, the bond with their mother was broken without warning. Abruptly, they moved from a place of warm, close, personal affection and succour to a state of motherlessness. Little wonder that the child with kwashiorkor so often has a look of maternal deprivation.

Table 9. Child's attendant for well-nourished controls and children with kwashiorkor

$\begin{array}{lcc} & \text { Kwashiorkor } & \text { Control } \\ \text { Mother } & 28 & 39 \\ \text { Other } & 22 & 11^{*} \\ \text { Changed when ill } & 14 & 5 \\ \text { Mother recalled } & 8 & 5^{\circ}\end{array}$

-The difference between groups was significant: $P<0.05\left(X^{2}\right.$ test).

(f) Significance of the attendant adult. As it may reflect social instability, identification of the child's attendant is most important (Table 9). A female attendant is not necessarily the patient's mother, but even if she is we need to know how long the two have been together: she may have been called back by the father when the child fell ill. The response to treatment is likely to be slow if the child is with an unfamiliar person: long-term health instruction may be offered ineffectively to a short-term guardian.

In this study, kwashiorkor children were less likely to have their mothers acting as attendants than were the children in the control group $(P<0.05)$. A mother was more likely to have been recalled in the kwashiorkor group when the child fell ill, and, belying appearances, was not the child's usual attendant. The most frequent substitute for the mother was a grandmother. 
Table Io. Child's rank in the family for well-nourished controls and children with kwashiorkor

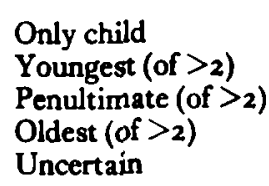

$\begin{array}{cc}\text { Kwashiorkor } & \text { Control } \\ \text { II } & 4 \\ 29 & 31 \\ 8 & 10 \\ 0 & 1 \\ 2 & 4\end{array}$

The difference between groups was not significant: $P>0.05\left(X^{2}\right.$ test $)$.

(g) The child's rank in the family. Several writers comment on the child with kwashiorkor being a 'deposed one' (Williams, 1935; McConnell, 1961). In this study, there was no statistical significance between the kwashiorkor group and the control when the groups were analysed according to the child's rank in the family (Table 10). A more significant association was that of the youngest child in the family whose mother was pregnant (Table II; $P<0.05$ ). The 'coming' child evidently deposes its predecessor before birth. It seems likely that the cultural custom of abrupt weaning and banishment during pregnancy contributes to this, according to our findings.

Table 11. Incidence of being youngest child and of pregnancy in families of wellnourished controls and children with kwashiorkor

$\begin{array}{lcc} & \text { Kwashiorkor } & \text { Control } \\ \text { Youngest child } & 29 & 3^{\mathbf{I}} \\ \text { Mother pregnant } & 7 & \text { I }\end{array}$

The difference between groups was significant: $P<0.05$ ( $\chi^{2}$ test).

When the subject was an only child, in the kwashiorkor group all eleven such children were from one parent families (four illegitimate, seven separated). None of these mothers was pregnant. By contrast, there were only four families in the control group who had a single child: three of these were stable, one expecting another baby (Table $12 ; P=0.009$ ).

Table 12. Parental state of the 'only' child for well-nourished controls and children with kwashiorkor

$\begin{array}{lcc} & \text { Kwashiorkor } & \text { Control } \\ \text { Together } & 0 & 3 \\ \text { Apart } & \text { II } & 1\end{array}$

The difference between groups was significant: $P=0.009$ (Fisher exact probability test).

(h) Father's work. Although family stability depends primarily on personal relationships, poverty can bring hardship as a threat to harmony. Under pressure, a man who can produce beans, eggs or milk on his own land may decide to sell them instead of feeding his children with them. Immigrants are unlikely to have land and may be able to find only unsociable or casual jobs. Men with a regular 
income would either be in professional posts or in a lower-paid, artisan job. Other work might vary from being a village chief to a self-employed shopkeeper.

Over all, it was difficult to gauge economic prosperity, but it was judged that a man in regular employment was likely to be better off in cash terms than someone who was either a peasant cultivator or unemployed. One family showed that wealth might even be a handicap to a child: they could afford a house-girl whose mismanagement of their son's diet resulted in the advent of kwashiorkor.

Over all, in a comparison of families where the father's income was thought to be low or non-existent with those where he had a better job (Table 13), significantly more children with kwashiorkor had fathers with a poor income $(P=0.0051)$.

Table 13. Father's occupation for well-nourished controls and children with kwashiorkor

\begin{tabular}{|c|c|c|c|}
\hline \multirow[b]{2}{*}{ Poor income: } & & Kwashiorkor & Control \\
\hline & Cultivator & 23 & 9 \\
\hline \multirow{7}{*}{ Better income: } & Unknown & 2 & 3 \\
\hline & Unemployed & 2 & 1 \\
\hline & Dead & I & 1 \\
\hline & Salaried & 4 & 18 \\
\hline & Other & 18 & 17 \\
\hline & Not asked & - & 1 \\
\hline & Total & 50 & 50 \\
\hline
\end{tabular}

The difference between groups was significant: $P=0.005$ (Fisher exact probability test).

\section{Summary of significant associations}

An East African child's age, sex and tribe can all influence vulnerability to kwashiorkor, but after matching for these variables the children studied were found to have ten social factors which were significantly associated with the disease (Table 14): I, attendant not the mother; 2, changed attendant to come for treatment; 3, new baby on the way; 4, parents separated; 5 , lone child of lone parent; 6 , weaned; 7 , why weaned; 8 , taken away from parents; 9, exiled at weaning; ro, poverty.

Table 14. Summary of significant associations for well-nourished controls and children with kwashiorkor

\begin{tabular}{|c|c|c|c|}
\hline & Kwashiorkor & Control & Significance \\
\hline $\begin{array}{l}\text { Child's attendant } \\
\text { Attendant changed when ill } \\
\text { Mother pregnant } \\
\text { Parents separated } \\
\text { Only child of split liaison }\end{array}$ & $\begin{array}{l}\text { Other } \\
\text { Yes } \\
\text { Yes } \\
\text { Yes } \\
\text { Yes }\end{array}$ & $\begin{array}{l}\text { Mother } \\
\text { No } \\
\text { No } \\
\text { No } \\
\text { No }\end{array}$ & $\begin{array}{l}P<0.05 t \\
P<0.05 t \\
P<0.05 t \\
P<0.05 t \\
P=0.009\end{array}$ \\
\hline $\begin{array}{l}\text { Weaned } \\
\text { Reason for weaning } \\
\text { Child living away from parents } \\
\text { Child sent away at weaning } \\
\text { Father's income }\end{array}$ & $\begin{array}{l}\text { Yes } \\
\text { Bad } \\
\text { Yes } \\
\text { Ye8 }\end{array}$ & $\begin{array}{l}\text { No } \\
\text { Good } \\
\text { No } \\
\text { No } \\
\text { Steady }\end{array}$ & $\begin{aligned} P & =0.00004^{\circ} \\
P & <0.005 t^{\circ} \\
P & <0.005 \dagger \\
P & =0.000022 \\
P & =0.0051^{\circ}\end{aligned}$ \\
\hline
\end{tabular}

-Fisher exact probability test.

$+\chi^{2}$ test. 
Factors $I-9$ relate to established or impending changes in the child's family structure, factors 6-9 affecting a child more personally and often painfully. Factor Io may be a continual source of potential, though not essential, deprivation. It is interesting that the statistical significances are greatest for the factors which touch the child's personal and emotional life most closely. Health educators may call these factors to mind by setting them out as an acrostic, based on the initial letters of a slogan which may then be taught to attendants: A Child Needs Personal Love With Which To Enjoy Protein.

Loving adults will do their best to make adequate provision and appropriate presentation of food for a growing child and will take an active part in feeding it to the child. Poverty and ignorance may contribute to social deprivation. Many of the children studied also had interwoven emotional deprivation, due to both acute and chronic loss of familiar loving care.

\section{Conclusion}

After World War II, Elsie Widdowson made her classic contribution to the theme of deprivation dwarfism (Widdowson, 195I). In her studies of orphanage children she, too, showed how children fail to grow properly if food is served without sustained loving care. The present conclusions are the same.

\section{Summary}

'The background to social and emotional deprivation is discussed and applied to a study of kwashiorkor in East African children. A group of 107 children with kwashiorkor was compared with I I controls. Age, sex and tribe were all found to have significances of their own: fifty of each group were therefore matched for these three factors. Ten other factors were found to be significant in the background of children with kwashiorkor, all of which could be associated with social or emotional deprivation or both (see Table ${ }_{14}$ ).

It is concluded that, in childhood, sustained personal care and affection are essential to normal growth.

The author is grateful to all who helped with this study either as patients, guardians, interpreters, health educators or cultural advisers. Iris Roscoe was secretary, David Thompson statistician (also Dr Andrews) and Paget Stanfield activator and catalyst. Thanks are due to them all.

\section{REFERENCES}

Bennett, F. J., (1963). Trop. geogr. Med. $15,148$.

Bowlby, J. (1971). Attachment and Loss, vol. 1. Attachment. Harmondsworth: Penguin Books. Clancy, H. \& McBride, G. (1975). Dev. Med. Chld Neurol. 17, 198.

Gardner, L. I. (1972). Sci. Am. 227, 76.

Klaus, M. H. \& Kennell, J. (1976). Maternal-Infant Bonding. St Louis Miss.: C. V. Mosby \& Co. Lynch, M. (1975). Lancet ii, 317 .

McConnell, J. F. (1961). Am. Y. Nurs. 61, 78 .

Parkin, M. \& Lacey, K. A. (1974). Archs Dis. Childh. 49, 417. 
Patten, R. G. \& Gardner, L. I. (1963). Growth Failure in Maternal Deprivation, chpt. I. Springfield, Ill.: Thomas.

Powell, G. F., Brosel, J. A., Raiti, S. \& Blizzard, R. M. (1967). New Engl. Y. Med. 276, i 279.

Robertson, J. (1962). Psychoanalytical Study of the Child, vol. 17, p. 245, [Ruth S. Eissler, editor]. International University Press.

Robertson, J. \& Robertson, J. (1971). Psychoanalytical Study of the Child, vol. 26, p. 264, [Ruth S. Eissler, editor]. Yale University Press.

Rutter, M. (1972). Maternal Deprivation Reassessed. Harmondsworth: Penguin Books.

Rutter, M. (1975). Helping Troubled Children. Harmondsworth: Penguin Books.

Stone, L. J., Smith, H. T. \& Murphy, L. B. (1974). [Editors] The Competent Infant. Tavistock Publications: London.

Welbourne, H. F. (1963). Afr. Chld Hlth. 14.

Widdowson, E. M. (1951). Lancet i, 1316.

Williams, A. E. (1943). Bamardo of Stepney. London: Allen and Unwin.

Williams, C. W. (1935). Lancet ii, 1151 .

Yarrow, L. J. \& Goodwin, M. S. (1974). The Competent Infant, no. 170, [L. J. Stone, H. T. Smith and L. B. Murphy, editors]. Tavistock Publications: London. 